\title{
Je současný člověk přirozeně mírumilovnější?
}

\section{Is Contemporary Human Naturally More Peaceful?}

\author{
Daniel Krchňák
}

\begin{abstract}
Abstrakt
Ve svém přispěvku stručně shrnu obsah knihy Stevena Pinkera The better angels of our nature: Why violence has declined a podrobím Pinkerovu analýzu vývoje násilí v lidských dějinách kritice. Dosavadní kritika tohoto díla ukazuje nejen na to, že Pinkerův popis jednotlivých historických období se zdá být na některých místech tendenční, ale že jeho obecná teze o zvyšující se mírumilovnosti společnosti není ze statistického hlediska prokázána. Připojím také vlastní kritiku Pinkerem identifikovaných psychologických změn, které podle jeho názoru vedly k bezprecedentní mírumilovnosti současného člověka. Představím argumenty, které zpochybňují bud' to, že tyto psychologické změny skutečně probíhají (proměna směrem k femininním hodnotám péče a k větším empatickým schopnostem), nebo že tyto proměny souvisejí s úbytkem násilí (přechod k utilitaristické morálce a k abstraktnímu myšlení).
\end{abstract}

\section{Klíčová slova}

úbytek násilí, rozum, empatie, proměna hodnot, Steven Pinker, pokrok

\begin{abstract}
In the paper I summarize the content of the influential book The better angels of our nature: Why violence has declined (by Steven Pinker) and afterwards criticize Pinker's analysis of the development of violence in the human history. I present already existing criticism of this book, which shows not only that Pinker's description of various historical periods is in some respect unbalanced, but also that his general claim about rising peacefulness of society is from a statistical point of view not proven. I also present my own criticism of identified psychological changes that have led - according to Pinker - to unprecedented peacefulness of contemporary people. I argue that we cannot be sure that either such psychological changes
\end{abstract}


really occur (in the case of the rise of the female-titled value system of care and in the case of rising empathy) or that these changes really led to increased peacefulness (rise of utilitarian values and of abstract thinking).

\section{Keywords}

violence decline, reason, empathy, value change, Steven Pinker, progress

V předkládané eseji se pokusím představit a kriticky zhodnotit knihu Stevena Pinkera The better angels of our nature: Why violence has declined. ${ }^{1}$ Tato kniha vydaná v roce 2011 předkládá velmi odvážnou a kontroverzní tezi. Snaží se nás přesvědčit, že přestože se nám může zdát, že všude kolem nás zuří válka, žijeme v nejmírumilovnější společnosti všech dob. Autor na tomto svém stanovisku trvá i po vydání svojí knihy, kdy vypukají války na Krymu a na Blízkém východě. ${ }^{2}$ Přestože se toto tvrzení může zdát neintuitivní, autor není jediným výzkumníkem, který takovouto (či obdobnou) pozici zastává. ${ }^{3}$ Pojd’me se nyní podívat, co konkrétně Pinker tvrdí.

\section{Pinkerovy teze}

Pinker podává analýzu lidské historie jako šesti různých proměn či trendů, které postupně zmenšovaly míru násilí. První fáze, která přinesla radikální snížení míry násilí, je podle Pinkera proces přechodu z anarchického uspořádání k prvním zemědělským společnostem (odehrávajícím se asi před pěti tisíci lety). Druhý pozitivní trend představuje civilizační proces (jehož počátek

1 Steven Pinker, The better angels of our nature: Why violence has declined, New York: Viking 2011.

2 Steven Pinker - Andrew Mack, The World Is Not Falling Apart, Slate, 22 December 2014. Dostupné online [04.08.2017]: http://www.slate.com/articles/news_and_politics/ foreigners/2014/12/the_world_is_not_falling_apart_the_trend_lines_reveal_an_increasingly_peaceful.html.

3 Přehled dalších autorů, kteří jsou přesvědčeni o bezprecedentní mírumilovnosti naší společnosti, podává např. Azar Gat, Is war declining - and why? Journal of peace research 50, 2012, č. 2, s. 149-157.

4 Pokud není uvedeno jinak, pocházejí tvrzení v této části textu z předmluvy diskutované knihy (S. Pinker, The better angels..., s. xxi-xxviii). 
je možné datovat do doby asi před půl tisíciletím), který označuje upevnění struktury feudálního zřízení v rámci velkých království s centrální mocenskou silou a komerční infrastrukturou. Třetím významným procesem byla podle Pinkera humanitární revoluce, která přišla s osvícenstvím (v 17. a 18. století) jako věkem Rozumu, kdy poprvé v historii vznikají organizované pacifistické skupiny bojující za zrušení sociálně uznávaných forem násilí (jako je despotismus, otroctví, pověrčivé zabíjení, násilí na zvířatech apod.). Čtvrtá fáze mírotvorného procesu nastala po konci 2. světové války, kdy světové velmoci přestaly proti sobě válčit a nastalo období tzv. Dlouhého míru (Long Peace). Páté období přišlo po konci Studené války, kdy organizované násilné konflikty všeho druhu klesají napříč světem (Pinker mluví o tomto trendu jako o Novém míru). Poslední proces - Revoluce občanských práv - časově mírně předchází předchozí proces. Pinker ho řadí jako poslední, protože se nezaměřuje na válečné násilí, ale spíše na „každodenní“ projevy násilí. Revoluce práv se zaměřuje na snížení násilí v rodině - násilí vưči ženám a dětem, projevy rasového násilí, násilí vůči homosexuálům a zvířatům. Občanská hnutí v druhé polovině 20. století a na počátku 21. století bojují proti různým formám takového násilí, které bylo v dřívějších dobách morálně neproblematizováno.

Pinker se však nezastavuje $u$ historické analýzy, ale činí také psychologickou analýzu násilnosti. $\mathrm{V}$ této souvislosti identifikuje pět tzv. vnitřních démonů - psychologických charakteristik, které vedou k násilnému jednání. Mezi ně řadí predátorství (instrumentální násilí), touhu po dominanci, odplatu, sadismus a ideologii. Vưči těmto negativním psychologickým silám staví Pinker čtyři „lepší anděly“ naší přirozenosti, kterými jsou empatie, sebeovládání, morálnost a rozum. Přestože Pinker předpokládá posun v převaze těchto psychologických sil (argumentuje především ve prospěch teze, že se v posledních staletích proměnilo chápání morálky ve prospěch mírumilovných hodnot a že rozumové schopnosti u lidí 20. století markantně stouply), ${ }^{5}$ identifikuje také externí faktory, které měly na snížení násilí vliv. Mezi ně počítá centrální spravování státu (s odkazem na Hobbese zde mluví o Leviathanovi), které dává státu monopol na užívání násilí, a tak působí preventivně proti svévolnému užívání násilí. Druhým faktorem je podle Pinkera příchod obchodu, ze kterého profitují obě dvě strany a který předpokládá nenásilí a důvěru. Třetím vnějším činitelem je feminizace společnosti, čímž se myslí jak demografický úbytek mladých mužư (kteří tvoří nejagresivnější

5 Viz S. Pinker, The better angels..., s. 636, 651-653.

6 Viz tamtéž, s. 688. 
část populace), tak také větší důraz na femininní hodnotu péče. Jako čtvrtý aspekt identifikuje Pinker proces rozšiřování empatického kruhu či referenční skupiny (tedy okruh bytostí, jejichž blaho bere člověk při svém jednání v potaz), který souvisí s kosmopolitizací současné společnosti. Nakonec mluví Pinker o tzv. eskalátoru rozumu, který umožňuje vymanit se z iracionálního kruhu násilí a naopak se přiklonit k racionálnímu přístupu k lidským záležitostem (jejímž hlavním cílem je dosažení co největšího blaha pro co největší počet zúčastněných). ${ }^{7}$

$\mathrm{V}$ předchozích odstavcích jsem předložil základní teze Pinkerovy knihy. Pinker podává na podporu svých tezí velké množství empirického i historického materiálu, které zde není možné podrobně analyzovat. Přesto se v následujícím textu pokusím ukázat, že jak na obecné úrovni, tak v některých konkrétních bodech je Pinkerova analýza historického vývoje násilí a jeho determinant problematická.

\section{Kritika Pinkerovy pozice}

Pinkerova kniha sklidila sice mnoho chvály (např. od Petera Singera), ale vysloužila si také značné množství kritiky. Kritizováno je i samotné kličcové tvrzení, že je náš svět méně násilný. Pravděpodobně nejvlivnější kritika pochází od Cirilla a Taleba, ${ }^{8}$ kteří argumentují, že tvrzení o relativní mírumilovnosti 20. století (teze o tzv. Dlouhém míru a Novém míru) pochází z naivního empirismu. Autoři ukazují na problematičnost statistických dat a modelů, které Pinker používá, a ukazují, že při aplikaci vhodnějších statistických nástrojů, které se vyrovnávají se specifiky historiografických dat, se hypotéza o relativním snížení krveprolití ve válečných konfliktech nepotvrzuje (respektive neukazuje se jako statisticky signifikantní).

Jako problematický se může zdát také fakt, že Pinker pracuje s relativními čísly. Když se podíváme na absolutní čísla, nabízí se nám zcela jiný obrázek. Podle Světové zprávy o násili a zdravi mělo 16. století 1,6 mil. válečných obětí, 17. století 6,1 mil. obětí, 18. století 7 mil. obětí, 19. století 19,4 mil. obětí a 20. století 109,7 mil. válečných obětí. ${ }^{9}$ I když jsou tato čísla zkreslená ná-

7 Viz tamtéz̆, s. 691.

8 Pasquale Cirillo - Nassim Nicholas Taleb, The Decline of Violent Conflicts: What Do the Data Really Say? 2016. The Nobel Foundation, Causes of Peace, Forthcoming. Dostupné online: [05.04.2017] https://ssrn.com/abstract=2876315.

9 Etienne G. Krug - Linda L. Dahlbeg - James A. Mercy - Anthony B. Zwi - Rafael Lozano 
růstem populace, zdá se z pohledu absolutních čísel silně neintuitivní tvrdit o světě 21. století, že je nejmírumilovnějším místem ve světových dějinách.

\section{Morálně retardovaný člověk minulosti?}

Je tedy problematické hodnotit současný svět na základě statistik jako mírumilovný. To však ještě nevyvrací tezi o mírumilovné povaze současného člověka. Pinker poukazuje např. na fenomén tzv. Revoluce práv, ${ }^{10}$ který popisuje snížení/eliminaci diskriminace rasových menšin a žen, snížení násilí na dětech a zviŕatech, resp. morální odsouzení všech těchto praktik, stejně jako ozbrojených konfliktů. Do kontrastu s moderním myšlením dává Pinker barbarské způsoby myšlení ostatních neosvícen(sk)ých kultur (zde navazuje na kontroverzní teorii civilizačního procesu Norberta Eliase).

Pinker používá jako své prameny např. texty jako je Illias, Bible, Středověká domáci kniha (popisující středověkou každodennost) nebo kniha etikety z 16 . století $O$ zdvořilosti chlapci̊, ve kterých bylo bráno násilí jako něco zcela normálního, či bylo dokonce oslavováno (poslední ze zmíněných knih ukazuje podle Eliase a Pinkera na neschopnost sebekontroly lidí tehdejší doby). Tuto evidenci je však nutné brát také s velkou obezřetností. Je vhodné zmínit, že Pinker není historik (ale psycholog a lingvista) a nemusí být tedy zvyklý chápat historické texty v adekvátním kontextu, což se může projevit tendenční interpretací historických pramenů. Pinker např́íklad tvrdí, že si křestané zvolili za svůj symbol „grafickou reprezentaci nechutného způsobu mučení a popravy“, ${ }^{11}$ což je „optikou dnešní citlivosti více než trochu děsivé u hnutí, které má být velkým morálním hnutím“. ${ }^{12}$ Takováto metoda interpretace připomíná popis konzumace živočišné potravy jako „strkání částí cizích těl do díry v hlavě“ ${ }^{13}$ Lidé, kteří provozují takto nechutné aktivity, bychom dnešní optikou mohli odsoudit velmi podobně.

(eds.), The World Health Report 2002, Geneva: WHO 2002. Citováno dle David Benatar, Better Never to Have Been: The Harm of Coming into Existence, New York: Oxford University Press Inc. 2006, s. 91.

10 S. Pinker, The better angels..., s. 378-481.

11 Tamtéž, s. 14.

12 Tamtéž.

13 Takovýto popis pochází, pokud se nemýlím, od britského spisovatele G. K. Chestertona, ale přes veškerou snahu se mi ho nepodařilo dohledat. 
Corry upozorňuje, že např. kresby z knihy Středověká domáci kniha, které Pinker prezentuje jako zobrazení středověké každodennosti a které obsahují mnoho brutálních vyobrazení, jsou ve skutečnosti pojmenovány Saturn a Mars a mají zobrazovat efekty způsobené těmito planetami, zatímco jiné kresby z této knihy zobrazují lidi chovající se velmi zdvořile. ${ }^{14}$

Také srovnání násilnosti státních a nestátních společenství je podle Corryho ${ }^{15}$ velmi nereprezentativní. Corry se zaměřuje na Pinkerův graf na straně 49, kde jsou všechny ne-sběračsko-lovecké kmeny (jichž jsou tisíce) reprezentovány 10 kmeny, z nichž pět je z Nové Guiney, čtyři z Amazonie a jeden z Evropy. Data o dvou amazonských kmenech Yanomami pocházejí z vysoce kontroverzních výzkumů N. Chagnona a další dva kmeny (Waorani a Jivaro) jsou ve srovnání s jinými kmeny extrémně brutální (Karsten, kterou Pinker cituje, označuje kmen Jivaro za nejválečnější indiánský kmen Jižní Ameriky). ${ }^{16}$

Podobně tendenční se zdá být zobrazení moderních demokratických států a osvícenské ideologie, kde naopak často vzniká dojem, že Pinker neoprávněně tyto státy omlouvá. Jeho odmítnutí souvislosti mezi osvícenstvím a např. jakobínským terorem, „vědeckým rasismem“ (reprezentovaným např. Francisem Galtonem) či bolševismem je neopodstatněné. Tzv. Dlouhý mír (trvající od 2. světové války) ignoruje krvavé střety velmocí mimo Evropu a Ameriku. korejskou a vietnamskou válku přičítá na vrub výhradně komunistické ideologii, zamlčuje použití chemických zbraní ve Vietnamu apod. ${ }^{17}$ Přestože Pinker představuje statistiky, které ukazují, že míra vražd v USA či ve Velké Británii v průběhu 20. století kolísala (a nikoliv klesala, jak by odpovídalo Pinkerově tezi), autor tento trend nijak nevysvětluje. ${ }^{18} \mathrm{~V}$ souvislosti s revolucí práv zvířat se Pinker nevyrovnává s faktem, že přestože má současný člověk větší zájem na blahu zvířat, zároveň plundruje přírodu bezprecedentním způsobem.

14 Viz Stephen Corry, Why Steven Pinker, Like Jared Diamond, Is Wrong, Truthout 2013. Dostupné online [04.04.2017]: http://www.truth-out.org/opinion/item/16880-the-case-ofthe-brutal-savage-poirot-or-clouseau-or-why-steven-pinker-like-jared-diamond-is-wrong.

15 Viz tamtéž.

16 Viz Rafael Karsten, Blood, Revenge, War and Victory Feasts among the Jibara Indians of Eastern Ecuador, Geografisk Tidsskrift 27, 1923, s. 1. Citováno dle S. Corry, Why Stephen Pinker...

17 Viz Edward S. Herman - David Peterson, Steven Pinker on the alleged decline of violence, International Socialist Review 86, 2012. Dostupné online [04.04.2017]: http://isreview.org/ issue/86/steven-pinker-alleged-decline-violence.

18 Viz John Gray, Steven Pinker is wrong about violence and war, The Guardian, 2015. Dostupné online [04.04.2017]: https://www.theguardian.com/books/2015/mar/13/john-graysteven-pinker-wrong-violence-war-declining. 
Zdá se tedy, že nejenže není jasné, zda je relativní úbytek násilí statisticky významným jevem, ale zároveň se ukazuje, že Pinkerem představovaný hobbesovský obraz předmoderního člověka jako „morálně retardovaného“19 jedince, kterému „chyběl nejen fyzický komfort, ale také vznešenější věci života jako poznání, krása a spojení s druhými lidmi“",20 a v protikladu k tomu moderního člověka jako racionálního mírumilovného aktéra, je značně zjednodušený.

\section{Mírumilovnost a psychologická proměna moderního člověka}

Pinkerem prezentovaný obraz dále podkopává námitka, kterou lze snadno odvodit ze samotné Pinkerovy knihy - že totiž mírumilovná povaha lidí současné společnosti nemusí mít nic společného s jakoukoliv psychologickou změnou, ale že příčina je ryze environmentální (Pinker se sice snaží vysvětlit snížení násilí pomocí vnějších faktorů, zároveň však předpokládá, že došlo $\mathrm{k}$ velké psychologické změně).

Pinkerův seznam vnějších faktorů zmíněný výše předpokládá výrazné změny psychologického aparátu - nejzřejmější je to patrně u eskalátoru rozumu. Jeden z nejvýznamnějších faktorů je však nezávislý na psychologické proměně - možnost státu efektivně potrestat neoprávněné použití násilí. A právě tento faktor se zdá být velmi významným při potlačování násilí. Např. nárůst kriminality v 60. a 70. letech v Americe byl patrně zastaven masivním nárůstem policejního a soudního aparátu. ${ }^{21}$

Také feminizace společnosti souvisí prokazatelně s čistě vnějšími, demografickými změnami. Stárnutí populace má patrně na násilnost populace pozitivní vliv, protože důležitým faktorem je počet mladých mužů ve společnosti. ${ }^{22}$

Pinker se však zmiňuje i o dalších vnějších faktorech, které mohly mít významný vliv na snížení násilného jednání u současných lidí. Jedním z takových

19 S. Pinker, The better angels..., s. 658.

20 Tamtéž, s. 693.

21 Viz Robert D. Putnam, Bowling alone: The collapse and revival of American community, New York: Simon and Schuster 2000, s. 144-146. Viz také Tomáš Klvaňa, Fenomén Trump: Posledni vzpoura bilých mužůu, Jarošov nad Nežárkou: Nakladatelství Pejdlova Rosička 2016, s. 57.

22 Viz James D. Fearon - David D. Laitin, Ethnicity, insurgency, and civil war, American political science review 97, 2003, No. 1, s. 75-90; Christian G. Mesquida - Neil I. Wiener, Human collective aggression: A behavioral ecology perspective, Ethology and sociobiology 17, 1996, č. 4, s. 247-262. Odkazy citovány dle S. Pinker, The better angels..., s. 688. 
činitelů mohl být nárůst materiálního bohatství. Pinker uznává, že tento faktor hraje velkou roli, zároveň však ukazuje, že míra násilí nekopíruje vždy ekonomickou vyspělost dané oblasti. ${ }^{23}$ Tento faktor se však jeví dobrým vysvětlením z pozice klasické psychologické teorie vysvětlující projevy agrese teorie frustrace-agrese, kde agrese vyplývá z frustrace potřeb či cílů jedince. ${ }^{24}$ Je snadné si domyslet, že v bohatších zemích jsou základní potřeby méně frustrovány, což dává lidem méně podnětů k agresivitě.

Dalším možným faktorem úbytku násilí, který sám Pinker uznává jako významný, je menší míra ozbrojenosti obyvatel západního světa. ${ }^{25}$ Mnoho agresivního chování se odehrává pod vlivem impulzivity (jako nedostatku sebekontroly). Zde hraje patrně značnou roli, jaké prostř̌edky má jedinec $\mathrm{v}$ takovou chvíli $\mathrm{k}$ dispozici.

Obraṫme se nyní k vnitřním faktorům, které podle Pinkera souvisí s nárůstem mírumilovnosti a morálním pokrokem. Pinker se zde odvolává na proměnu hodnot $\mathrm{v}$ osvícenství směrem $\mathrm{k}$ utilitaristickým hodnotám - uznání lidského blaha jako jediné skutečné hodnoty. Takovýto obrat patrně mưže přispět k odsuzování násilí, na druhé straně je nutné upozornit, že proklamované hodnoty mohou často vést $\mathrm{k}$ opačným výsledkům. Francouzská revoluce např. nepřinesla (přinejmenším bezprostředně) deklarované hodnoty volnosti, rovnosti a bratrství, ${ }^{26}$ a jak ukazuje sám Pinker, tak hnutí hippies, které si kladlo mír jako nejvyšší hodnotu, s sebou přineslo masivní nárůst kriminality v USA. ${ }^{27}$

Také tvrzení o nahrazování maskulinních hodnot cti za femininní hodnoty péče se nezdá být neproblematické. Je sice pravda, že v dnešním světě mají ženy větší moc než dříve (a tedy mohou více ovlivňovat obecně zastávané hodnoty), na druhou stranu metaanalytická studie zkoumající vývoj maskulinních a femininních rysů v průběhu času došla k závěru, že ženy si spíše osvojují mužské rysy, zatímco muži pokračují v ne-osvojování ženských rysů. ${ }^{28}$

23 Viz S. Pinker, The better angels..., s. 675-676.

24 Viz John Dollard - Neal Miller et al., Frustration and aggression, New Haven - CT: Yale University Press 1939. Citováno dle Thomas G. Reio Jr., Supervisor and coworker incivility: Testing the work frustration-aggression model, Advances in Developing Human Resources 13, 2011, č. 1, s. 54-68: 55.

25 Viz S. Pinker, The better angels..., s. 673.

26 Viz Iain McGilchrist, The master and his emissary: The divided brain and the making of the western world, New Haven - London: Yale University Press 2012, s. 345-346.

27 Viz S. Pinker, The better angels..., s. 106-116.

28 Viz Jean M. Twenge, Changes in masculine and feminine traits over time: A meta-analysis, 
Když se podíváme na výzkumné výsledky, zdá se také problematické mluvit o „rozšiřování empatického kruhu“. Metaanalytická studie srovnávající empatické schopnosti napříč časem ukazuje, že v posledních desetiletích (konkrétně mezi lety 1979-2009) se míra empatického zájmu mezi americkými studenty snižovala. ${ }^{29}$ Podobně jako u předchozí charakteristiky vzniká tedy pochybnost, zda skutečně k inkriminovanému psychologickému procesu, který je vnímán jako mediátor mírumilovnosti, došlo.

Nakonec se zdá jako problematický také faktor, který Pinker nejvíce spojuje s psychologickou proměnou moderního člověka - akcelerace abstraktního rozumu. Na rozdíl od předchozích dvou procesů zde není pochyb o existenci tohoto procesu. ${ }^{30} \mathrm{U}$ tohoto jevu však není zdaleka zřejmé, že je skutečně mírotvorným prostředkem. Není jasné, proč by schopnost kontrafaktuálního či proporčního myšlení měla vést ve většině případů k morálnímu či pacifistickému jednání. Myšlenkové experimenty mohou být např. využívány pro argumentaci ve prospěch zrušení absolutního imperativu zakazujícího násilí. ${ }^{31}$ Proporční myšlení může stejně dobře jako k optimalizaci trestního systému sloužit k optimalizaci plánování vraždy. Autor sám pak přiznává, že behaviorismus, který můžeme považovat za výsledek používání abstraktního rozumu, může vést k přesvědčení o inkoherenci otázky po tom, ,jaké to je být krysou“ vedoucí následně k devalvaci jejího utrpení ${ }^{32}$ Pinkerova snaha prokázat spojení mírumilovnosti s nárůstem abstraktního rozumu statistickými daty se zdá být také značně nedostačující. Pinker zde spoléhá výhradně na korelace korelací - obecná míra inteligence koreluje s abstraktním myšlením a mírumilovnosti a s ní spojené fenomény korelují s obecnou mírou inteligence. Takovýto druh spojení se zdá být poměrně slabou evidencí.

Existuje naopak evidence, že lidé s psychopatologickými diagnózami, které se nejvíce podílejí na násilném jednání - psychopati (lidé s antisociální poruchou osobnosti) a schizofrenici nemají patrně poškozené abstraktní

Sex roles 36, 1997, č. 5-6, s. 305-325.

29 Viz Sara H. Konrath - Edward H. O‘Brien - Courtney Hsing, Changes in dispositional empathy in American college students over time: A meta-analysis, Personality and Social Psychology Review 15, 2011, č. 2, s. 180-198.

30 Popis tohoto jevu je znám pod pojmem Flynnův efekt. Viz např. James R Flynn, What is intelligence?: Beyond the Flynn effect, Cambridge: Cambridge University Press 2007.

31 Do této kategorie patř́i myšlenkové experimenty, kde použití násilí zabrání celkově větší újmě, např. shození tlouštíka do kolejiště u myšlenkového experimentu výhybky zabrání smrti vícero lidí, mučení teroristy umožní přežití mnoha nevinných lidí ap.

Viz S. Pinker, The better angels..., s. 455. 
myšlení. ${ }^{33}$ Výzkum Owena, Cuttinga a Davida naopak naznačuje, že v situaci, kdy je běžný rozum a logika v konfliktu, uvažují schizofrenici vice logicky než běžní lidé. ${ }^{44}$ Sám Pinker pak na jednom místě uvádí, že myšlení útočníka se překrývá s myšlením vědce (kterého můžeme brát jako prototyp člověka využívajícího abstraktní myšlení) - oba zaujímají distancovaný (detached), amorální postoj, oba dbají na komplexitu situace a oba věří, že je újma zcela vysvětlitelná. ${ }^{35}$ Také již zmiňovaný decivilizační proces v 60. letech v Americe vedl $\mathrm{k}$ velkému nárůstu násilí a probíhal paralelně s Flynnovým efektem historickým procesem nárůstu abstraktního myšlení. ${ }^{36}$

Pokud se tedy podíváme na Pinkerovu teorii kritickým okem, zdá se, že pokud se vůbec rozhodneme zaobírat se statisticky (zatím) nevýznamným jevem relativního úbytku násilí, pak jeho př́ičiny patrně nespočívají v morální nadřazenosti současných občanů, ale především $\mathrm{v}$ př́íhodných socioekonomických podmínkách, do kterých se narodili. ${ }^{37}$

\section{Mgr. Daniel Krchňák}

Katedra filozofie, Filozofická fakulta, Masarykova univerzita

Arna Nováka 1, 60200 Brno, Česká republika

362596@mail.muni.cz

33 Že psychopati nemají sníženou inteligenci, dokládá například studie Ian Barkataki Veena Kumari - Mrigenda Das et al., Volumetric structural brain abnormalities in men with schizophrenia or antisocial personality disorder, Behavioural brain research 169, 2006, č. 2, s. 239-247. Viz také Robert D. Hare, The psychopathy checklist-Revised, Toronto: MultiHealth Systems 1991.

34 Viz Gareth S. Owen - John Cutting - Anthony S. David, Are people with schizophrenia more logical than healthy volunteers?, The British Journal of Psychiatry 191, 2007, č. 5, s. $453-454$.

35 Viz S. Pinker, The better angels..., s. 495.

36 K decivilizačnímu procesu viz S. Pinker, The better angels..., 106-116.

37 Toto tvrzení ještě neimplikuje, že některé postoje současného člověka (např. odmítání otroctví) nejsou morálně pokrokovější. Znamená to ale, že není důvod se domnívat, že kdyby se dnešní člověk se svým kognitivním vybavením narodil do jiné doby, osvojil by si na jejich základě tyto pokrokovější pozice. 